\title{
ANALISIS BUKU TEKS TEMATIK INTEGRATIF BERBASIS SCIENTIFIC APPROACH DAN AUTHENTIC ASSESSMENT PADA KURIKULUM 2013
}

\begin{abstract}
Abstrak
Penelitian ini bertujuan untuk mendeskripsikan muatan tematik integratif, scientific approach, dan authentic assessment pada buku teks Kurikulum 2013. Penelitian ini merupakan penelitian analisis konten yang menggunakan pendekatan kualitatif. Subjek penelitian ini adalah tiga buku teks Kurikulum 2013 kelas V Tema I yang diterbitkan oleh Puskurbuk, Non Puskurbuk 1, dan Non Puskurbuk 2 tahun 2014. Hasil dari penelitian ini adalah sebagai berikut. (1) Semua buku teks yang dianalisis telah memenuhi sebagian besar muatan tematik integratif, yaitu pada aspek pengalaman bermakna dan student centered learning. Sebagian kecil indikator yang belum terpenuhi adalah pada aspek multidisipliner karena kekurang-telitian dan perbedaan pandangan yang digunakan oleh penulis. (2) Semua buku teks yang dianalisis telah memenuhi semua muatan scientific approach. Kegiatan mengumpulkan informasi merupakan kegiatan yang mendominasi. (3) Semua buku teks yang dianalisis telah memenuhi sebagian besar muatan authentic assessment. Rubrik penilaian pada buku teks berupa contoh format penilaian yang dapat dikembangkan oleh guru.
\end{abstract}

\author{
Degi Alrinda Agustina, Ali Mustadi \\ STKIP Modern Ngawi \\ Email: gigi_alrin@yahoo.co.id
}

Kata Kunci: buku teks, tematik integratif, scientific approach, authentic assessment.

\section{AN ANALYSIS OF INTEGRATIVE THEMATIC TEXTBOOKS BASED ON SCIENTIFIC APPROACH AND AUTHENTIC ASSESSMENT IN CURRICULUM 2013}

\begin{abstract}
This research aims to describe content of the integrative thematic, the scientific approach, and the authentic assessment in the textbooks of Curriculum 2013. This research was a content analysis using the qualitative approach. The subjects were three textbooks of Curriculum 2013 for Grade V on the $1^{\text {st }}$ theme, published by Puskurbuk, Non Puskurbuk 1, and Non Puskurbuk 2 in 2014. The result of this study are as follows. (1) All textbooks have fulfilled most of the thematic integrative content, namely the aspect of meaningful experiences and student centered learning. A small portion of unfulfilled indicator is the multidisciplinary aspect because lack of precision and different views used by the author. (2) All textbooks have fulfilled all the scientific approach content. Experimenting are activities that dominate. (3) All textbooks have fulfilled most of the authentic assessment content. Rubric assessment in the form of a textbooks are example of the assessment format that can be developed by teachers.
\end{abstract}

Keywords: textbooks, integrative thematic, scientific approach, authentic assessment. 


\section{PENDAHULUAN}

Pendidikan merupakan bagian yang penting dalam meningkatkan sumber daya manusia dalam suatu negara, bahkan pendidikan menjadi tolok ukur majunya suatu negara. Negara yang memiliki sistem pendidikan yang baik, akan mempengaruhi kemajuan negara tersebut. pendidikan juga merupakan upaya untuk menciptakan sumber daya manusia yang berkualitas. Salah satu upaya yang dilakukan pemerintah dalam mewujudkan tujuan pendidikan nasional adalah melalui pengembangan kurikulum. Kurikulum di Indonesia telah mengalami beberapa kali perubahan dalam 10 tahun terakhir, yaitu pada tahun 2004 dengan Kurikulum Berbasis Kompetensi (KBK), pada tahun 2006 dengan Kurikulum Tingkat Satuan Pendidikan (KTSP), dan pada tahun 2013 dikembangkan Kurikulum 2013. Kurikulum 2013 menekankan kompetensi siswa pada 3 aspek, yaitu sikap, keterampilan, dan pengetahuan. Tujuan implementasi tercantum pada Mendikbud (2013a) bahwa pemilahan ini diperlukan untuk menekankan pentingnya keseimbangan fungsi sebagai manusia seutuhnya yang mencakup aspek spiritual dan aspek sosial sebagaimana analisis diamanatkan dalam tujuan pendidikan nasional.

Pelaksanaan Kurikulum 2013 pada Sekolah Dasar/Madrasah Ibtidaiyah dilakukan melalui pembelajaran dengan pendekatan tematik terpadu. Meinbach, Rothlein \& Fredericks (1995, p.5) menyatakan bahwa " $A$ thematic approach to learning combines structured, squential, and well-organized strategies, activities, children's literature, and materials used to expand a particular concept". Sebuah pendekatan tematik untuk belajar menggabungkan materi secara terstruktur, berurutan, dan terorganisir dan strategi yang baik, berupa kegiatan-kegiatan, bacaan anakanak, dan bahan yang digunakan untuk memperluas konsep tertentu. Pendekatan integrasi yang digunakan dikelas $\mathrm{V}$ adalah integrasi multidisipliner yang dilakukan tanpa menggabungkan kompetensi dasar tiap mata pelajaran sehingga tiap mata pelajaran masih memiliki kompetensi dasarnya sendiri. Menurut Adeyemi (2010, p.11) \& Al Hassan (2012, p.403) "The multidisciplinary approach denotes the teaching of concepts across more than two subjects or disciplines. The instruction may be organized on fundamental issues common to the three academic disciplines instead of teaching the students in a disjointed and unconnected manner". Pendekatan miltidisipliner yang digunakan dalam Kurikulum 2013 bertujuan untuk mempermudah peserta didik dalam menyatukan dan menghubungkan konsep antar materi pelajaran sehingga memperoleh pembelajaran yang bermakna. Selain menggunakan model multidisipliner dan mengutamakan pengalaman bermakna bagi peserta didik, pembelajaran tematik integratif mengarahkan peserta didik untuk aktif membangun pengetahuan dalam proses pembelajaran, sehingga pembelajaran mengarah pada pembelajaran berpusat pada peserta didik (student centered learning). Hal tersebut sejalan dengan Rusman (2014, p.257) yang menyatakan bahwa model pembelajaran tematik lebih menekankan pada keterlibatan peserta didik dalam belajar atau mengarahkan siswa secara aktif terlibat dalam proses pembelajaran. Oleh karena itu, pembelajaran tematik integratif juga mengarahkan peserta didik secara aktif terlibat dalam mengeksplorasi, mengkonstruksi dan merefleksi pengetahuan.

Pembelajaran yang digunakan pada Kurikulum 2013 adalah scientific approach. Scientific approach merupakan suatu pembelajaran dengan pendekatan ilmiah, yang dikembangkan dari metode ilmiah (scientific method) agar peserta didik dapat ,mengkonstruksi pengetahuan layaknya peneliti. Metode ilmiah awalnya diterapkan pada mata pelajaran IPA, akan tetapi sekarang berkembang pada mata pelajaran lain, bahkan pembelajaran dengan tematik integratif. Sebagaimana yang disampaikan Gerde, Schachter, \& Wasik (2013, p.322) "using the scientific method to guide children's thinking during science activities integrates children's language, literacy, math, and science development". Metode ilmiah digunakan untuk membimbing pemikiran peserta didik selama aktivitas ilmiah yang mengintegrasikan bahasa, literasi, matematika dan IPA. Scientific approach dalam Kurikulum 2013 meliputi mengamati (observing), menanya (questioning), mengumpulkan informasi (experimenting), mengasosiasikan (associating), dan mengkomunikasikan (communicating). 
Kegiatan-kegiatan tersebut mengarahkan peserta didik agar mengkonstruksi pengetahuan secara mandiri dan mengkomunikasikan proses dan hasilnya untuk selanjutnya pengetahuan tersebut dikonfirmasi oleh guru.

Proses pembelajaran sangat erat hubungannya dengan penilaian. Pada kurikulum 2013 digunakan penilaian autentik (authentic assessment). Authentic assessment merupakan penilaian yang menekankan pada kegiatan nyata yang dilakukan peserta didik untuk menggambarkan kemampuan peserta didik sesungguhnya. Authentic assessment sering disamakan dengan performance assessment, sebagaimana ditegaskan oleh Settlage \& Southerland (2012, p.165) bahwa performance assessment juga disebut dengan authentic assessment, karena kegiatan penilaian tersebut adalah autentik untuk peserta didik mempelajari konsep dan keterampilan. Nitko \& Brookhart (2011, p.249) menekankan beberapa jenis performance assessment meliputi tugas terstruktur, kinerja alami, proyek, simulasi, dan portofolio. Penilaian otentik diharapkan dapat menggambarkan peserta didik secara nyata dalam hal sikap dan pengetahuan juga yang diwujudkan dalam keterampilan yang dilakukan. Hal ini sejalan dengan konsep Kurikulum 2013 bahwa penilaian tersebut meliputi penilaian sikap, yang meliputi sikap spiritual dan sikap sosial, penilaian pengetahuan dan penilaian keterampilan. Ketiga penilaian ini membantu guru untuk mengetahui pencapaian dan perubahan peserta didik selama atau setelah pembelajaran yang dapat diterapkan dalam kehidupan nyata.

Implementasi bahan ajar tematik integratif pada Kurikulum 2013, diwujudkan dalam bentuk buku teks. Buku teks pada Kurikulum 2013, berbeda dengan kedua kurikulum sebelumnya. Buku teks Kurikulum 2013 disusun langsung oleh Kemdikbud melalui tim pengembang, kemudian ditelaah oleh Badan Standar Nasional Pendidikan (BSNP) untuk selanjutnya dijadikan sumber utama dalam proses pembelajaran. Reynold (Ho \& Hsu, 2011, p.93) menyatakan "textbooks is the key to curriculum development and implementation through dissemination to teachers and students..." Oleh karena itu, buku teks yang ada harus dapat menyajikan bahan pembelajaran yang bermakna bagi peserta didik sebagai subjek belajar dan guru sebagai pendidik dalam upaya mengembangkan kurikulum. Cunningsworth (Roseni, 2014, p.417) menyatakan bahwa "textbooks are an effective resource for self directed learning, an effective resource for presenting materials by the teachers, a source of ideas and activities, a reference source for students, a syllabus that reflects pre-determined learning objectives, and support for less experienced teachers who have yet to gain in confidence. Oleh karena itu, buku teks pelajaran menjadi seperangkat alat yang berperan sangat penting dalam pembelajaran.

Peran vital buku teks tidak diiringi dengan kesuksesan distribusi buku teks di lapangan. Pada kenyataannya distribusi buku teks tersebut terjadi keterlambatan diberbagai daerah, termasuk Kota Yogyakarta, sebagaimana yang dikutip oleh Niti Bayu Indrakrista (2014, p.1) pada tanggal 12 Agustus 2014, bahwa dari total 287 sekolah di Kota Pelajar, hanya delapan sekolah yang distribusi bukunya sudah beres. Kedelapan sekolah itu adalah tingkat SD. Berdasarkan hasil observasi, beberapa sekolah mengatasi keterlambatan tersebut dengan mengunduh dan mencetak sendiri buku teks tersebut serta menggunakan softcopy untuk ditayangkan lewat LCD proyector. Beberapa sekolah lainnya yang memilih menggunakan buku teks lain dalam proses pembelajaran selama menunggu disribusi tiba di sekolah. Buku teks Tema 1 dari berbagai penerbit pada masingmasing tingkatan kelas adalah alternatif yang digunakan oleh guru pada proses pembelajaran Kurikulum 2013 ketika terjadi keterlambatan buku.

Buku teks yang tersedia di beberapa toko tersebut belum ditelaah oleh BSNP. Hal ini terlihat pada situs resmi BSNP, yaitu www.bsnpindonesia.org yang diakses pada 30 Juni 2014, Djuandi (2014) menyatakan BSNP pada tahun 2014 baru membuka untuk telaah buku teks pelajaran bagi SMA/ MA kelompok peminatan. Oleh karena itu, masih belum diketahui kelayakan isi, bahasa, penyajian, dan kegrafikaan sebagai komponen standar yang akan ditelaah pada buku teks kurikulum 2013. Kelayakan isi yang dimaksud termasuk Standar Isi yang terdiri dari Kompetensi Inti (KI) dan Kompetensi Dasar (KD) yang dapat dianalisis 
melalui muatan tematik integratif, pembelajaran berbasis scientific approach dan penilaian berbasis authentic assessment, ketiga aspek tersebut mencakup pada Standar Isi, Standar Proses dan Standar Penilaian yang menjadi ruh dalam Kurikulum 2013. Aspek lainnya mencakup kesesuaian dengan karakteristik peserta didik, terutama peserta didik SD.

Buku teks yang diterbitkan oleh Pusat Kurikulum dan Perbukuan (Puskurbuk) telah ditelaah BSNP dan ditentukan kelayakannya oleh Mendikbud sebagaimana prosedur yang dinyatakan oleh Mendiknas (2008) pasal 4 ayat (1) dan (2). Kelayakan buku teks yang diterbitkan oleh Puskurbuk telah ditetapkan oleh Mendikbud (2013b). Jadi, hasil telaah BSNP tidak dipublikasikan sehingga publik belum mengetahui secara detail tentang keberadaan muatan-muatan utama pada Kurikulum 2013. Oleh karena itu, buku teks yang diterbitkan oleh Puskurbuk tetap menjadi obyek penelitian.

Buku teks kurikulum 2013 pada Tema 1 pada kelas $\mathrm{V}$ dari berbagai penerbit menjadi salah satu buku teks yang digunakan dalam proses pembelajaran kurikulum 2013 ketika terjadi keterlambatan buku teks dari Kemendikbud. Buku teks Tema 1 mencakup materi pertama tentang pengenalan benda-benda dilingkungan sekitar. Oleh karena itu sebagai materi pertama diharapkan memuat aspek utama dalam kurikulum 2013 yaitu tujuan, proses dan penilaian sebagai pembiasaan awal bagi guru dan peserta didik dalam proses pembelajaran kurikulum 2013. Selain itu, pemilihan Tema 1 Kelas V sebagai upaya mempersiapkan guru dan peserta didik untuk implementasi tahun berikutnya agar tidak terjadi miskonsepsi dalam implementasi kurikulum 2013. Oleh karena itu dibutuhkan juga analisis buku teks tematik integratif kurikulum 2013 berbasis scientific approach dan authentic assessment Tema 1 Kelas V sebagai upaya membantu sekolah dan guru dalam menentukan buku teks yang akan digunakan dalam proses pembelajaran yang sesuai dengan tuntutan Kurikulum 2013.

\section{METODE}

Penelitian ini menggunakan pendekatan kualitatif dengan jenis penelitian analisis konten. Penelitian ini berusaha untuk memahami pesan simbolik pada sebuah dokumen. Pesan simbolik yang dimaksud adalah muatan materi yang berkaitan dengan tematik integratif, scientific approach dan authentic assessment sedangkan dokumen yang dianalisis adalah buku teks tematik integratif Kurikulum 2013.

Survei buku teks yang digunakan untuk penelitian ini dilakukan di SD se kota Yogyakarta yang sudah menerapkan Kurikulum 2013 selama 3 semester. Penelitian ini dilakukan di Kota Yogyakarta. Penelitian ini dilaksanakan pada bulan Januari sampai Februari 2015.

Subjek Penelitian

Subjek penelitian ini adalah buku teks pelajaran tematik integratif pada Kurikulum 2013 kelas V Tema I Benda-benda di Lingkungan Sekitar yang diterbitkan oleh Puskurbuk, penerbit Erlangga (Non Puskurbuk 1), dan Yudhistira (Non Puskurbuk 2) tahun 2014. Buku teks dari Puskurbuk, terdiri dari Buku Guru dan Buku Siswa sedangkan buku dari penerbit Non Puskurbuk 1, dan Non Puskurbuk 2 terdiri dari 1 buku teks masingmasing penerbit, yang menunjukkan bahwa 1 buku berfungsi sebagai buku guru dan buku siswa dalam proses pembelajaran. Pemilihan buku tersebut berdasarkan buku yang paling banyak digunakan di 15 SD se kota Yogyakarta yang sudah menerapkan Kurikulum 2013 selama 3 semester.

Teknik pengumpulan data dalam penelitian ini adalah pembacaan dan pencatatan yang cermat terhadap adalah buku teks pelajaran tematik integratif pada Kurikulum 2013 kelas V Tema I Benda-benda di Lingkungan Sekitar. Instrumen yang digunakan dalam penelitian ini adalah lembar analisis dokumen yang disusun berdasarkan landasaan teori tentang tematik integratif, scientific approach dan authentic assessment. Kisi-kisi lembar analisisis dokumen sebagai berikut.

Tabel 1. Kisi-Kisi Instrumen

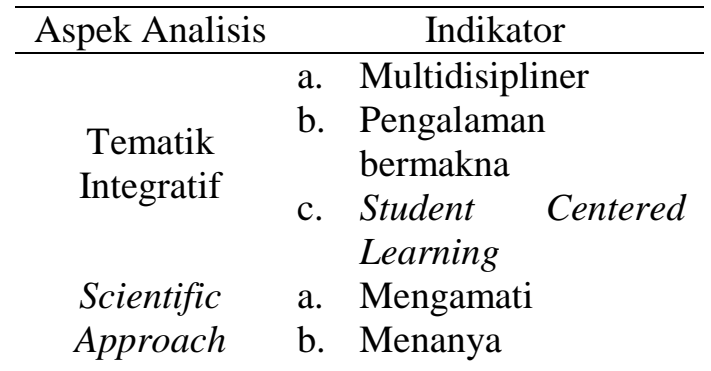




\begin{tabular}{cll} 
& c. Mengumpulkan \\
& & informasi \\
& d. Mengasosiasikan \\
& e. Mengkomunikasikan \\
& a. Tugas Terstruktur \\
Authentic & b. Kinerja Alami \\
Assessment & c. Proyek \\
& d. Komunikasi pribadi \\
& e. Portofolio \\
\hline
\end{tabular}

Keabsahan Dokumen

Validitas instrumen dan data yang digunakan adalah validitas semantis dan pemeriksaan oleh ahli. validitas semantis adalah validitas yang digunakan untuk mengetahui kesesuaian kategori dari analisis teks sesuai dengan makna teks-teks dalam konteks yang dipilih (Krippendorf, 2004, p.323).

Reliabilitas yang digunakan adalah stabilitas dan reproduktabilitas. Stabilitas dilakukan dengan pencatatan dan pemeriksaan data diulangi sebanyak 3 kali untuk memperoleh konsistensi data. Reproduktabilitas dilakukan dengan pemeriksaan oleh teman sejawat yang terdiri dari 2 orang, yaitu dari Program Studi Linguistik Terapan untuk melakukan pemeriksaan pada aspek bahasa, dan dari Program Studi Sains melakukan pemeriksaan aspek materi.

Teknik Analisis Data

Teknik analisis data yang digunakan pada penelitian ini adalah skema analisis konten menurut Krippendorf (2004: 83), yang tercantum sebagai berikut.

\section{Unitizing}

Unit yang dimaksud adalah subjek penelitian. Pada penelitian ini unitizing dilakukan dengan mengumpulkan buku teks Kurikulum 2013 kelas V Tema I Benda-benda di Lingkungan Sekitar dari Puskurbuk, Non Puskurbuk 1, dan Non Puskurbuk 2.

Sampling

Penentuan sampel tersebut merupakan cara untuk membatasi observasi dengan merangkum semua jenis unit yang ada sehingga terkumpul unit-unit yang memiliki muatan yang sama. Sampling dilakukan dengan memfokuskan pada aspek utama dalam Kurikulum 2013, yaitu tematik integratif, scientific approach dan authentic assessment.

\section{Recording}

Pencatatan dan deskripsi dilakukan terhadap konten buku yang berkaitan dengan aspek tematik integratif, scientific approach dan authentic assessment berdasarkan konstruk analisis yang telah disusun berdasarkan teori dan konteks Kurikulum 2013.

Reducing

Pada penelitian ini, reduksi data dilakukan selama tahap analisis data, hanya dengan menghilangkan hal-hal yang tidak relevan dengan penelitian, yang dikaitkan dengan aspek-aspek yang tercantum pada pertanyaan penelitian. Pencatatan hasil terhadap aspek yang tidak berkaitan dengan tematik integratif, scientific approach dan authentic assessment dapat dihilangkan. Selain itu, reduksi data dilakukan untuk menyederhanakan data dengan mengklasifikasikan setiap pembelajaran dan meringkas data yang sejenis.

Inferring

Tahap ini dilakukan dengan menganalisis data lebih jauh dengan mencari makna data unit-unit yang ada. Dengan begitu, tahap ini menjembatani antara sejumlah data deskriptif dengan pemaknaan. Konstruksi analitis (analitical construct) digunakan dengan melakukan pemetaan indikator-indikator pada masing-masing aspek yang dijabarkan dari variabel yang dianalisis. Temuan dicatat dan dimaknai sesuai dengan konstruk analisis tersebut. Hasil reduksi untuk memperoleh jawaban atas pertanyaan-pertanyaan yang dapat disimpulkan dari hasil analisis.

Narrating

Menarasikan merupakan cara untuk menjawab pertanyaan penelitian dengan mengkaji hasil analisis dengan teori yang relevan. Narasi berisi informasi-informasi penting bagi pengguna penelitian agar memahami dan mengambil keputusan terhadap hasil penelitian.

\section{PEMBAHASAN}

Deskripsi dan Analisis Data

Tematik Integratif

Aspek tematik integratif meliputi multidisipliner, pengalaman bermakna, dan pembelajaran berpusat pada peserta didik (student centered learning). Muatan tersebut 
dianalisis dan dimaknai pada setiap pembelajaran pada masing-masing buku teks.

\section{Multidisipliner}

Pada muatan multidisipliner, data yang diperoleh adalah jumlah materi mata pelajaran pada masing-masing pembelajaran bervariasi, dengan minimal mengintegrasikan 2 mata pelajaran dalam 1 pembelajaran. Buku Puskurbuk mencantumkan 3 dan 4 materi mata pelajaran pada setiap pembelajaran, dengan jumlah materi mata pelajaran yang sering muncul adalah 4 mata pelajaran. Buku Non Puskurbuk 1 juga mencantumkan 3 dan 4 materi mata pelajaran, dengan jumlah materi mata pelajaran yang paling sering muncul adalah 3 mata pelajaran. Buku Non Puskurbuk 2 mencantumkan 2 dan 3 materi mata pelajaran, dengan jumlah materi pelajaran yang paling sering adalah 3 mata pelajaran. Hubungan antar mata pelajaran berupa pembahasan tema yang sama dan rangkaian cerita. Buku Puskurbuk dan Buku Non Puskurbuk 2 hubungan antar mata pelajaran dengan rangkaian cerita dilengkapi dengan tokoh-tokoh yang menjadi pemeran utama dari subtema 1 sampai subtema 3. Sedangkan, pada Buku Non Puskurbuk 1 hubungan antar mata pelajaran dengan hubungan dan kaitan antar materi pelajaran. Beberapa KD tidak sesuai dengan materi dan Permendikbud serta peletakan KD yang terbalik antar mata pelajaran.

\section{Pengalaman bermakna}

Pada muatan pengalaman bermakna, data yang diperoleh adalah materi yang dipelajari peserta didik berkaitan dengan diri sendiri dan lingkungan sekitar. Materi berkaitan dengan diri dan lingkungan sekitar peserta didik dan bermanfaat untuk diterapkan dalam kehidupan sehari-hari. Tema pada buku yang dianalisis tentang benda-benda di lingkungan sekitar, jadi muatan pada buku teks sudah sesuai dengan tema sehingga peserta didik dapat menerapkan hal-hal positif yang diperoleh pada pembelajaran dalam kegiatan sehari-hari. Selain itu, kegiatan yang tercantum juga mengarahkan peserta didik untuk melakukan berbagai pengalaman belajar. Ada beberapa kegiatan yang tercantum pada buku teks, membutuhkan kemampuan peserta didik yang lebih tinggi, seperti kampanye dan penyuluhan pada Buku Non Puskurbuk 1 halaman 49 dan 74-75. Kegiatan merencanakan penanggulangan terhadap isu-isu alam dan sosial, terkesan sulit dengan mengabaikan karakteristik peserta didik.

\section{Student Centered Learning}

Pada muatan Student Centered Learning, data yang diperoleh adalah mengarahkan peserta didik berinteraksi dengan lingkungan alam dan lingkungan sosial, Mengarahkan peserta didik untuk menggali informasi secara rinci melalui berbagai kegiatan yang tercantum, dan refleksi pembelajaran secara mandiri dan bersama. Refleksi mandiri biasanya diperoleh dari pemaknaan karena biasanya tidak tercantum pada buku teks, hanya buku teks yang diterbitkan pemerintah yang mencantumkan kolom untuk refleksi diri, tetapi beberapa kolom tersebut juga masih belum mewakili indikator yang hendak dicapai peserta didik.

\section{Scientific Approach}

Aspek scientific approach meliputi mengamati, menanya, mengumpulkan informasi, mengasosiasikan, dan mengkomunikasikan. Muatan tersebut dianalisis pada setiap kegiatan dari masing-masing buku teks.

\section{Mengamati}

Kegiatan mengamati merupakan langkah awal sebelum memasuki proses pembelajaran yang menekankan keaktifan peserta didik. Pada buku teks peserta didik diminta untuk membaca, melihat, mendengar dan menyimak sebagai cara untuk menarik perhatian dan menggali rasa ingin tahu peserta didik. Kegiatan mengamati tercantum secara implisit maupun eksplisit dalam buku teks yang dianalisis. Kegiatan membaca terdiri dari membaca teks dan informasi. Membaca teks ditunjukkan dengan keberadaan teks yang telah disediakan, teks tersebut terdiri dari beberapa paragraph yang digunakan untuk melatih keterampilan peserta didik dalam membaca dan memahami teks. Membaca informasi terdiri dari informasi yang membantu peserta didik untuk mempersiapkan melakukan kegiatan selanjutnya. Informasi tersebut biasanya berisi tentang pengetahuan awal yang hendaknya dipahami peserta didik 
sebelum melakukan kegiatan selanjutnya. Kegiatan melihat terdiri dari melihat gambar, lingkungan sekitar, dan hasil percobaan. Kegiatan melihat bertujuan sebagai langkah awal menarik minat dan untuk menggali pengetahuan awal peserta didik terhadap suatu materi yang akan dipelajari. Kegiatan menyimak terdiri dari menyimak guru yang membacakan teks dan prosedur pembuatan karya seni. Menyimak adalah mendengarkan dengan seksama disertai dengan teks Kegiatan mendengarkan terdiri dari mendengarkan guru membaca teks cerita. Mendengarkan adalah kegiatan menggunakan indera pendengaran, yaitu telinga untuk memperoleh informasi. Mendengarkan berbeda dengan menyimak karena menyimak mendengarkan disertai dengan teks, sedangkan mendengarkan yang tidak disertai dengan teks. Kegiatan menyimak dan mendengarkan memiliki frekuensi kemunculan yang lebih sedikit dibandingkan kegiatan melihat dan membaca.

\section{Menanya}

Kegiatan menanya merupakan langkah kedua untuk mengetahui rasa ingin tahu peserta didik setelah mengamati. Pada buku teks peserta didik diminta berdiskusi terhadap informasi baru dan membuat pertanyaan untuk menggali rasa ingin tahu peserta didik. Kegiatan menanya tercantum secara tertulis dalam bentuk kata perintah dalam buku teks yang dianalisis. Diskusi tentang informasi merupakan salah satu kegiatan menanya. Kegiatan tersebut dimaknai dari aktivitas yang dilakukan peserta didik ketika diskusi yaitu saling bertanya jawab untuk menggali informasi dari tugas yang diberikan. Diskusi tentang informasi ini merupakan kegiatan menanya kepada teman kelompok. Kegiatan diskusi tentang informasi dimaknai dari buku teks dengan adanya kata perintah. Kegiatan menanya muncul sebagai aktivitas untuk menggali hasil pengamatan antar anggota kelompok. Rasa ingin tahu yang dimiliki peserta didik tersebut akan mengarahkan untuk berpikiran terbuka (open minded) dalam menerima pendapat dan pengetahuan dari diskusi. Data kegiatan menanya yang diperoleh dari buku teks, pada diawali dengan aktivitas mengamati lingkungan sekitar. Membuat pertanyaan merupakan kegiatan peserta didik menyusun pertanyaan berdasarkan $5 \mathrm{~W}+1 \mathrm{H}$. Data kegiatan membuat pertanyaan yang muncul berupa membuat pertanyaan untuk menggali informasi dari teks. Kegiatan membuat pertanyaan ini membantu peserta didik untuk mempermudah memahami informasi dari teks. Kegiatan membuat pertanyaan juga membantu peserta didik untuk mengungkap hal yang ingin ditemukan. Semakin banyak pertanyaan yang dibuat, maka akan semakin banyak informasi yang diperoleh yang dapat membantu menambah pengetahuan peserta didik. Kegiatan Membuat pertanyaan merupakan kegiatan menanya yang frekuensi kemunculannya lebih sedikit dibandingkan dengan diskusi tentang informasi.

\section{Mengumpulkan informasi}

Kegiatan mengumpulkan informasi merupakan aktivitas peserta didik yang sesungguhnya yang mengarahkan peserta didik aktif untuk mulai melakukan kegiatan untuk membangun dan mengkonstruksi pengetahuan. Kegiatan mengamati dan menanya merupakan kegiatan awal untuk mengantarkan dan mempersiapkan peserta didik untuk memulai kegiatan ini. Kegiatan mengumpulkan informasi yang tercantum pada buku teks meliputi mengeksplorasi, mencoba, melakukan percobaan, mengumpulkan data dan membaca sumber selain buku teks. Kegiatan tersebut tersebar merata pada setiap pembelajaran pada masing-masing buku teks, sehingga kegiatan mengumpulkan informasi tersebut bervariasi. Kegiatan mengeksplorasi merupakan kegiatan menggali informasi dari gambar, teks, dan lingkungan sekitar. Mengeksplorasi adalah aktivitas peserta didik untuk menggali hal yang berkaitan dengan materi untuk menemukan suatu konsep pengetahuan. Pada buku teks, kegiatan mengekplorasi sering berdampingan dengan kegiatan mengamati. Kegiatan mengeksplorasi pada buku teks ditunjukkan dengan pertanyaanpertanyaan dan tugas-tugas yang telah disediakan buku teks untuk menggali hal yang dimaksud. Pertanyaan-pertanyaan yang digunakan untuk mengeksplorasi biasanya berkaitan dengan analisis kritis, seperti kata tanya "Mengapa" dan "Bagaimana". Hal tersebut jelas berbeda dengan mengamati, mengamati hanya berusaha untuk menjawab pertanyaan "apa". Kegiatan mencoba merupakan kegiatan 
menerapkan prosedur yang telah dipelajari yang terdiri dari mengerjakan soal, mempraktikkan teknik olahraga, dan membuat karya. Kegiatan melakukan percobaan merupakan kegiatan merekayasa suatu objek untuk memperoleh pengetahuan pada muatan mata pelajaran IPA dan Matematika. Peserta didik diarahkan terlebih dahulu untuk memiliki pengetahuan awal yang ditunjukkan dengan informasi yang diberikan sebelum melakukan percobaan. Peserta didik yang melakukan percobaan mendapat pengetahuan yang lebih nyata dan lengkap dibandingkan dengan pengetahuan dari informasi awal karena membuktikan informasi awal yang diperoleh.

Kegiatan mengumpulkan data merupakan kegiatan mencari data relevan tentang suatu informasi melalui observasi, wawancara, dan studi pustaka. Kegiatan pada buku teks ini membantu keterampilan peserta didik untuk aktif terlibat dalam memperoleh pengetahuan. Peserta didik dapat berinteraksi dengan lingkungan, narasumber, dan sumber tertulis secara langsung. Mengumpulkan data juga merupakan cara agar peserta didik terjun langsung pada situasi nyata di sekitarnya. Kegiatan ini dapat melatih kepekaan peserta didik terhadap keadaan lingkungan sekitar. Kegiatan ini terdapat pada muatan SBdP, IPA, IPS, dan PPKn. Kegiatan membaca sumber selain buku teks merupakan kegiatan membaca untuk menginspirasi kegiatan lainnya. Pada buku teks kegiatan ini berbeda dengan mengumpulkan data, karena mengumpulkan data langsung diarahkan untuk memperoleh pengetahuan. Kegiatan ini pada buku teks diantaranya untuk menginspirasi dalam membuat karya. Kegiatan ini pada buku teks terdapat pada muatan Bahasa Indonesia, IPA dan SBdP.

\section{$\underline{\text { Mengasosiasikan }}$}

Kegiatan mengasosiasikan merupakan kegiatan yang mengarahkan peserta didik untuk mengasosiasikan berkaitan dengan pengetahuan awalnya dihubungkan dengan pengetahuan baru dari hasil yang diperolehnya melalui aktivitas mengumpulkan informasi. Kegiatan mengasosiasikan yang tercantum pada buku teks meliputi mengolah informasi, mengkategorikan, menghubungkan dengan fenomena atau informasi terkait dan menyimpulkan. Kegiatan
Mengolah informasi merupakan kegiatan yang dilakukan peserta didik untuk memaknai data yang diperoleh. Kegiatan tersebut ditunjukkan dengan pertanyaan-pertanyaan yang mengarahkan peserta didik untuk memaknai data yang diperoleh dari kegiatan sebelumnya. Pada buku teks, mengolah informasi terdiri dari mengolah informasi berdasarkan teks atau informasi, data dan pemahaman yang dimiliki oleh peserta didik saat ini. Mengolah informasi berdasarkan teks atau informasi biasanya berupa pertanyaan-pertanyaan yang membutuhkan jawaban tidak langsung tertulis pada teks, melainkan membutuhkan pemahaman teks terlebih dahulu, baru bisa menjawab pertanyaan dengan tepat. Mengolah informasi berdasarkan data yang diperoleh dari kegiatan sebelumnya. Pada buku teks, data yang tercantum dimaknai sesuai dengan pengetahuan awal yang diperoleh sehingga memperoleh pemahaman yang berguna untuk menjawab pertanyaan yang tersedia. Mengolah informasi berdasarkan pemahaman yang dimiliki peserta didik untuk mengungkap pengetahuan peserta didik sebelum memulai kegiatan berikutnya. Pertanyaan-pertanyaan yang muncul, jawabannya tidak berdasarkan teks maupun data, melainkan berdasarkan pengetahuan peserta didik secara umum terhadap sesuatu.

Kegiatan mengkategorikan merupakan kegiatan peserta didik untuk menentukan kelompok dari beberapa objek yang disajikan berdasarkan pemahaman terhadap suatu konsep. Kegiatan menghubungkan fenomena/informasi terkait pada buku teks dibedakan menjadi fenomena dan informasi. Kegiatan menghubungkan fenomena melatih peserta didik untuk berpikir logis, berkaitan dengan pengetahuan dan lingkungan sekitar. Pada buku teks, sebagian besar meminta peserta didik untuk menghubungkan pengetahuan yang diperoleh dengan fenomena di lingkungan sekitar, diantaranya peserta didik menentukan sikap dan memberi alasan terhadap sikap tersebut. Kegiatan menghubungkan informasi melatih peserta didik untuk berpikir kritis. Hal tersebut berkaitan dengan pengetahuan awal dan pengetahuan baru yang diperoleh peserta didik untuk menjadi pengetahuan yang utuh. Pada buku teks, kegiatan menghubungkan informasi ditunjukkan dengan meminta mencari informasi 
dari teks yang berkaitan dengan materi sebelumnya. Kegiatan menyimpulkan merupakan kegiatan mengasosiasikan yang terakhir karena telah memperoleh suatu kesimpulan dari seluruh kegiatan yang telah dilaksanakan. Kegiatan menyimpulkan terdiri dari menyimpulkan hasil percobaan, diskusi, eksplorasi. Kegiatan menyimpulkan dari percobaan merupakan kegiatan peserta didik untuk memperoleh informasi dan pengetahuan yang telah diasosiasikan dengan pengetahuan awal sebelumnya melalui percobaan sederhana. Kegiatan percobaan mengantar peserta didik untuk memperoleh informasi baru, informasi tersebut dikaitkan dengan pengetahuan awal agar diperoleh suatu kesimpulan. Menyimpulkan hasil diskusi juga merupakan salah satu kegiatan mengasosiasikan. Proses asosiasi terjadi ketika peserta didik saling menyampaikan pendapat terhadap pengetahuan awal masing-masing dan pemahaman masing-masing terhadap suatu informasi. Peserta didik mulai mengasosiasikan pengetahuannya dengan pengetahuan anggota kelompoknya sehingga dapat diperoleh kesimpulan dari proses tersebut. Pada buku teks, menyimpulkan juga dapat dilakukan setelah kegiatan eksplorasi. Peserta didik melakukan ekplorasi terhadap suatu objek di lingkungannya, dari kegiatan tersebut peserta didik memperoleh pola untuk membangun pengetahuannya.

\section{Mengkomunikasikan}

Kegiatan mengkomunikasikan merupakan kegiatan untuk menyampaikan hasil, baik secara tertulis maupun lisan. Mengkomunikasikan bertujuan untuk memantapkan konsep yang sudah tepat dan meluruskan konsep yang kurang tepat. Serangkaian kegiatan yang telah dilakukan mulai dari mengamati hingga mengasosiasikan seringkali menyebabkan kebingungan konsep pada peserta didik. Oleh karena itu, mengkomunikasikan sebagai jalan untuk klarifikasi antara guru dengan peserta didik, maupun dengan teman sebaya. Kegiatan mengkomunikasikan yang tercantum pada buku teks meliputi menyajikan hasil secara tertulis dan lisan.

\begin{tabular}{lccr}
\multicolumn{2}{c}{ Menyajikan } & hasil secara & tertulis \\
merupakan kegiatan & peserta & didik & untuk \\
menuliskan hasil kegiatan yang & telah
\end{tabular}

dilaksanakan. Kegiatan menyajikan hasil secara tertulis bertujuan untuk melatih keterampilan menulis peserta didik. Menulis dengan kalimat sendiri dan sesuai dengan Ejaan Yang Disempurnakan (EYD) adalah hal yang diharapkan dapat dicapai oleh peserta didik. Hal tersebut dapat dicapai dengan pembiasaan. Buku Puskurbuk mengarahkan peserta didik untuk menulis pada setiap kegiatan yang dilaksanakan. Hal tersebut berbeda dengan kedua buku lainnya yang mengarahkan kegiatan menulis lebih sedikit. Keberadaan kegiatan ini biasanya terintegrasi dengan kegiatan yang lain. Pada buku teks, kegiatan menyajikan hasil secara tertulis merupakan kegiatan peserta didik menuliskan hasil kegiatan berupa laporan, deskripsi gambar, dan informasi teks. Pada buku teks, menyajikan laporan terdiri dari kolom, tabel dan menulis pada kertas atau buku tugas.

Menyajikan hasil secara lisan membantu untuk melatih keterampilan berbicara peserta didik. Peserta didik menyampaikan sesuai dengan pengalaman dan hasil yang diperoleh. Pada buku teks, menyajikan hasil secara lisan dibagi menjadi dua, yaitu individu dan kelompok. Menyajikan hasil secara lisan dapat dilakukan secara individu sebagai hasil kerja individu. Hasil yang disajikan dapat berupa karya, menceritakan gambar dan hasil membaca. Karya yang dibuat oleh peserta didik ditampilkan di depan kelas sebagai bentuk apresiasi terhadap karya yang dibuat. Karya tersebut dapat berupa gambar, pantun, puisi, syair maupun kesenian daerah. Pada buku teks, menyajikan hasil secara lisan juga dapat dilakukan secara berkelompok. Muatan yang disajikan secara berkelompok adalah hasil diskusi dan hasil percobaan. Kegiatan ini dilakukan sebagai bentuk klarifikasi terhadap pengetahuan baru yang diperoleh dikaitkan dengan pengetahuan awal. Pengetahuan yang diperoleh dari hasil diskusi merupakan hasil pemikiran antar anggota kelompok berdasarkan pengamatan dan diskusi untuk saling melengkapi informasi yang dimiliki masing-masing anggota kelompok. Pengetahuan tersebut harus segera diklarifikasi agar tidak berlanjut pada konsep yang salah.

Kegiatan mengumpulkan informasi merupakan kegiatan yang mendominasidari lima kegiatan tersebut. Kegiatan pada scientific 
approach memiliki kekhasan pada buku teks. Kekhasan tersebut memberikan makna bahwa pembelajaran dapat dilaksanakan secara bervariasi tanpa melepaskan muatan scientific approach. Pembelajaran yang bervariasi dengan berinteraksi dengan lingkungan alam dan sosial membantu peserta didik untuk menambah pengalaman belajarnya.

\section{Authentic Assessment}

Aspek authentic assessment meliputi tugas terstruktur, kinerja alami, proyek, komunikasi pribadi dan portofolio. Muatan tersebut dianalisis dan diberi pemaknaan setiap halaman pada masing-masing buku teks. Pemaknaan dilakukan dengan melihat kegiatan yang tercantum pada buku teks, dimana kegiatan tersebut mengarahkan pada penilaian tertentu untuk mengetahui kemampuan peserta didik. Pada satu kegiatan biasanya menggunakan berbagai jenis penilaian. Hal ini perlu dilakukan untuk menggambarkan kemampuan sebenarnya yang dimiliki peserta didik. Beberapa kegiatan pada buku teks tersebut sebagai upaya untuk mengungkap kemampuan peserta didik yang sesungguhnya melalui sikap, pengetahuan, dan keterampilan.

\section{$\underline{\text { Tugas Terstruktur }}$}

Tugas tersruktur adalah kegiatan yang digunakan untuk mengetahui kemampuan peserta didik yang sesungguhnya berdasarkan penguasaan suatu konsep atau pengetahuan. Peserta didik diminta menyajikan secara tertulis melalui paper-pencil task, dan meminta mempraktikkan hasil pengetahuannya melalui demonstrasi. Paper-pencil task pada buku teks, terdiri dari tiga jenis, yaitu pilihan ganda, isian dan uraian. Pilihan ganda sebagian besar muncul pada buku Non Puskurbuk 1 dan Non Puskurbuk 2 pada evaluasi setiap subtema. Buku Puskurbuk seluruh kegiatan paper-pencil task berupa uraian. Isian muncul pada soal evaluasi setiap subtema Buku Non Puskurbuk 1 dan Buku Non Puskurbuk 2 dengan proporsi soal yang lebih sedikit dibandingkan soal pilihan ganda. Sebagian besar soal-soal tersebut masih berkisar pada $\mathrm{C} 1$ dan $\mathrm{C} 2$ menurut taksonomi Bloom. Sedangkan tipe soal uraian terdiri dari $\mathrm{C} 1$ sampai dengan $\mathrm{C} 4$. Masing-masing buku teks muncul jenis soal uraian, tetapi proporsinya berbeda-beda. Buku Puskurbuk mendominasi keberadaan soal uraian tersebut. Sebagian besar paper-pencil task pada buku teks tidak dilengkapi dengan rubrik jawaban sehingga belum jelas sistem penilaian yang digunakan. Hal tersebut ditemukan pada Buku Non Puskurbuk 2 dan Buku Non Puskurbuk 1. Pada Buku Puskurbuk, sebagian besar paper-pencil task yang disertai dengan penilaian aspek sikap dan keterampilan, sehingga jika dimaknai penilaian tersebut dikombinasikan dengan observasi. Kegiatan demonstrasi merupakan kegiatan yang digunakan untuk membuktikan pemahaman yang diperoleh peserta didik berupa keterampilan. Peserta didik menunjukkan keterampilannya sebagai bentuk pemahaman terhadap pengetahuan yang diperoleh. Pada buku teks, demonstrasi muncul pada muatan mata pelajaran PJOK. Demonstrasi sebagai bentuk implementasi terhadap pemahaman yang diperoleh. Sebagian besar berupa teknik atau cara berinteraksi dengan suatu objek.

\section{$\underline{\text { Kinerja alami }}$}

Kinerja alami merupakan kegiatan yang dilakukan peserta didik dalam proses pembelajaran. Fokus kegiatan ini adalah dengan penilaian yang dilakukan guru untuk menilai peserta didik dalam keadaan yang alami. Pada buku teks, kinerja alami yang dilakukan peserta didik dapat berupa paper-pencil task dan demonstrasi seperti yang telah dijelaskan sebelumnya, maupun kegiatan proyek yang lebih kompleks. Selain berkaitan dengan proses, hasil juga menjadi bagian penilaian berupa presentasi lisan terhadap hasil. Kinerja alami digunakan untuk menilai aspek sikap, keterampilan dan pengetahuan melalui observasi, penilaian diri, dan penilaian teman sejawat. Observasi merupakan kegiatan penilaian dengan mengamati peserta didik secara langsung dalam kegiatan pembelajaran. Rubrik penilaian observasi sebagian besar ditemukan pada Buku Puskurbuk melalui Buku Guru yang memberikan penilaian secara rinci. Pada Buku Non Puskurbuk 2 tidak ditemukan sama sekali rubrik penilaian observasi. Pada Buku Non Puskurbuk 1 terdapat satu rubrik yang mewakili rubrik satu kegiatan tertentu pada setiap pembelajaran. Penilaian diri merupakan cara yang digunakan untuk mengevaluasi diri terhadap pemahaman 
suatu informasi. Refleksi diri hanya tercantum pada Buku Puskurbuk terdiri yang terdiri dari indikator pencapaian dari setiap pembelajaran. Penilaian teman sejawat merupakan penilaian yang dilakukan peserta didik terhadap peserta didik lainnya berdasarkan pengamatan dan pengalamannya. Penilaian teman sejawat muncul pada aktivitas diskusi yang dilakukan peserta didik untuk menilai kemampuan peserta didik lainnya pada Buku Puskurbuk, yaitu Buku Guru. Penilaian teman sejawat muncul pada Buku Guru dalam bentuk rubrik penilaian diskusi pada pembelajaran 2, 5, dan 6 pada subtema 1 .

\section{Proyek}

Proyek merupakan kegiatan dalam jangka waktu tertentu untuk memperoleh sesuatu, baik pengetahuan maupun karya. Pada buku teks, sebagian besar kegiatan yang tercantum adalah kegiatan berbasis proyek. Proyek tersebut berupa proyek individu, proyek kelompok, maupun kombinasi dari keduanya. Proyek individu adalah kegiatan yang dilakukan peserta didik selama jangka waktu tertentu untuk menerapkan maupun untuk menggali pengetahuan yang diperoleh sebelumnya. Pada buku teks, proyek individu terdiri dari berbagai kegiatan, diantaranya membaca berbagai sumber, membuat karya, ekplorasi lingkungan sekitar sebagai upaya menerapkan dan menggali pengetahuan. Kegiatan proyek individu juga dilengkapi dengan hasil nyata yang menggambarkan usaha yang dilakukan. Proyek kelompok merupakan kegiatan yang sama dengan proyek individu, hanya saja dilakukan lebih dari dua orang. Pada buku teks, dalam proyek kelompok biasanya telah ditentukan jumlahnya, diantaranya 4-5 orang, maupun 3-6 orang. Proyek kelompok menjadi variasi kegiatan dari buku teks agar peserta didik saling berinteraksi untuk bersama menggali pengetahuan. Pada buku teks, proyek kelompok terdiri dari diskusi dan percobaan. Proyek individu dan proyek kelompok juga bisa dilaksanakan dalam satu kegiatan. Pada buku teks, kegiatan tersebut secara proses dilaksanakan secara kelompok, akan tetapi hasil yang diperoleh dari proses tersebut disajikan secara individu. Rubrik penilaian sebagian besar ditemukan pada buku Puskurbuk dan sebagian kecil pada buku Non Puskurbuk 1. Buku Non
Puskurbuk 2 sama sekali tidak mencantumkan rubrik penilaian proyek tersebut. Rubrik penilaian proyek kombinasi perlu menjadi perhatian bagi penulis buku teks, karena tidak diperoleh contoh sama sekali. Hal ini akan menyulitkan guru dalam menggabungkan dan memisahkan penilaian kelompok maupun individu.

\section{$\underline{\text { Komunikasi Pribadi }}$}

Komunikasi digunakan peserta didik untuk menyajikan hasil dari proses pembelajaran secara verbal. Pada buku teks, komunikasi terdiri dari presentasi lisan dan dramatisasi. Presentasi lisan merupakan kegiatan peserta didik untuk menyampaikan dan menceritakan hasil yang diperoleh pada pembelajaran. Presentasi lisan tersebut menyajikan hasil karya non sastra, yaitu pengetahuan dan karya berupa gambar. Dramatisasi merupakan kegiatan peserta didik untuk menyajikan hasil dengan ekspresi yang disesuaikan dengan hasil yang diperoleh. Pada buku teks, dramatisasi berupa penyampaian hasil karya sastra yang berupa puisi, pantun, dan syair. Dramatisasi digunakan untuk menilai keterampilan mengekspresikan karya sastra. Selain itu, yang membedakan penilaian presentasi dan dramatisasi adalah karya yang disajikan dan ekspresi yang digunakan.

\section{Portofolio}

Portofolio merupakan kumpulan dari hasil-hasil proyek yang telah dilakukan peserta didik. Portofolio digunakan untuk mengetahui perkembangan peserta didik selama periode waktu tertentu. Pada buku teks, jenis portofolio yang muncul adalah karya terbaik dan kemajuan belajar. Karya terbaik merupakan portofolio yang berisi kumpulan hasil kreativitas peserta didik dalam membuat berbagai karya. Karya tersebut dapat digunakan untuk mengetahui perkembangan kreativitas terutama keterampilan peserta didik selama periode waktu tertentu. Karya terbaik muncul pada muatan SBdP dan Bahasa Indonesia. Karya pada muatan SBdP berupa topeng, gambar ilustrasi dan imajinasi, dan ronce. Karya pada muatan Bahasa Indonesia berupa karya sastra, yaitu puisi, pantun, dan syair. Kemajuan belajar merupakan portofolio yang digunakan untuk mengetahui perkembangan pengetahuan yang dimiliki 
peserta didik pada periode waktu tertentu. Berbeda dengan karya terbaik yang digunakan untuk melihat perkembangan kreativitas. Pada buku teks, kegiatan yang dimaknai menghasilkan portofolio secara tertulis. Kemajuan belajar terdiri dari laporan dan tugas tertulis. Rubrik penilaian sebagian besar masih belum disusun oleh penulis buku teks, sehingga perlu manjadi bahan evaluasi.

Buku teks Kurikulum 2013 menerapkan authentic assessment dengan mengarahkan peserta didik mengarahkan pada berbagai kegiatan nyata, Kegiatan tersebut juga membantu mengarahkan guru untuk menggunakan kombinasi dari berbagai jenis penilaian untuk mengetahui kemampuan peserta didik yang sesungguhnya. Rubrik penilaian pada buku teks berupa contoh format penilaian, sehingga guru perlu mengembangkannya lebih lanjut agar dapat diterapkan sesuai dengan pembelajaran yang dilakukan.

\section{Pembahasan}

\section{Tematik Integratif}

Pada buku teks Kurikulum 2013, muatan tematik integratif merupakan aspek penting dalam struktur kurikulum SD. Muatan multidisipliner menjadi salah satu aspek yang tidak terpenuhi secara utuh karena kekurang telitian dan perbedaan pandangan yang digunakan oleh penulis. Oleh karena itu, hal ini perlu menjadi bahan evaluasi. Kekurang telitian diantaranya pada jumlah mata pelajaran yang diintegrasikan. Adeyemi (2010, p.11) \& Hassan (2012, p.403) menyatakan "The multidisciplinary approach denotes the teaching of concepts across more than two subjects or disciplines". Model ini mencakup lebih dari dua mata pelajaran. Namun, pada kenyataan yang ditemukan pada buku teks, masih ada yang terdiri dari dua mata pelajaran saja yang terintegrasi. Hal tersebut ditemukan pada buku Non Puskurbuk 2 terutama di pembelajaran 5 dan 6 setiap subtema. Buku Non Puskurbuk 1 dan Puskurbuk telah memenuhi kriteria dengan minimal tiga mata pelajaran yang terintegrasi.

Perbedaan pandangan yang digunakan penulis berkaitan dengan cara mengintegrasikan mata pelajaran dalam suatu pembelajaran. Adeyemi (2010, p.11) \& Al Hassan (2012, p.403) "The instruction may be organized on fundamental issues common to the three academic disciplines instead of teaching the students in a disjointed and unconnected manner". Oleh karena itu, antar mata pelajaran harus berhubungan isu-isu mendasarnya. Temuan yang diperoleh pada buku teks, terdapat dua jenis hubungan antar mata pelajaran tersebut. Hubungan antar mata pelajaran tersebut yaitu materi yang berkaitan antar muatan mata pelajaran dan rangkaian cerita yang utuh pada pembelajaran yang dilengkapi dengan tokoh. Hubungan antar materi tersebut terdapat pada buku Non Puskurbuk 1. Hal tersebut sesuai dengan teori diatas. Sedangkan yang menggunakan rangkaian cerita adalah buku Puskurbuk dan Non Puskurbuk 2. Rangkaian cerita menjadi penghubung antar kegiatan dan antar muatan mata pelajaran. Rangkaian cerita tersebut dilengkapi dengan tokoh-tokoh yang menjadi pemeran utama dari subtema 1 sampai subtema 3. Buku teks pada peserta didik sebagai sumber belajar tertulis yang perlu dipahami oleh peserta didik melalui kegiatan membaca. Buku teks Puskurbuk dan Non Puskurbuk 2 tersebut menggunakan pendekatan bahasa utuh (wholelanguage approach) yang sejalan dengan Berk (2012, p.415), yaitu dari awal, peserta didik diperlihatkan pada teks dalam bentuk utuh, seperti cerita sehingga mereka dapat memahami fungsi komunikatif bahasa tulis.

Keberadaan pengalaman langsung pada buku teks yang merupakan bagian dari pengalaman bermakna dan student centered learning dapat membantu peserta didik untuk meningkatkan daya serap (retention) peserta didik terhadap materi yang dipelajari. Hal tersebut sejalan dengan Piramida Belajar (Learning Pyramid) dalam tulisan Lalley \& Miller (2007, p.68) bahwa daya serap dengan melakukan pengalaman nyata adalah $90 \%$. Hal tersebut jelas berbeda jauh dengan hanya mendengarkan guru mengajar, yaitu $20 \%$.

\section{Scientific Approach}

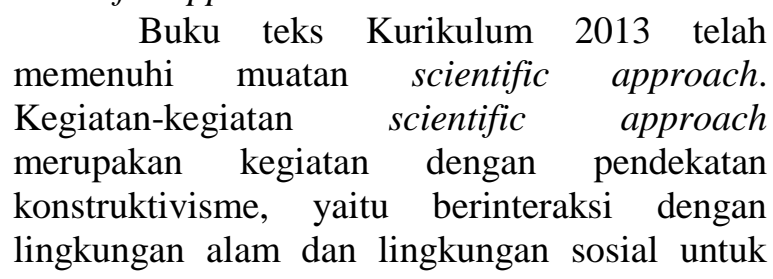


membangun pengetahuan. Berinteraksi dengan lingkungan alam dapat membantu membangun pengetahuan yang sejalan dengan pendapat Schunk (2012, p.334) bahwa pembelajaran terjadi ketika anak-anak mengalami konflik kognitif dan terlibat dalam asimilasi dan akomodasi untuk membangun dan mengubah struktur-strukur internal. Oleh karena itu, pembelajaran dengan berinteraksi dengan lingkungan fisik membantu peserta didik untuk membangun struktur internal untuk memahami suatu hal. Selain itu, Schunk (2012, p.340) menambahkan kembali bahwa lingkungan sosial mempengaruhi kognisi melalui "alat-alatnya", yaitu objek-objek kulturalnya, serta bahasa dan intuisi-intuisi sosial. Interaksi sosial membantu mengoordinasi ketiganya. Oleh karena itu interaksi sosial juga dibutuhkan dalam suatu proses pembelajaran.

Pada buku teks Non Puskurbuk 1 ditemukan dua kegiatan yang kurang sesuai dengan karakteristik peserta didik terutama berkaitan dengan perkembangan intelektual. Dua kegiatan tersebut berkaitan dengan membuat kegiatan kampanye dan penyuluhan. Hal tersebut bertolak belakang dengan Piaget (Santrock, 2009, p.55) bahwa peserta didik SD masuk dalam tahap operasional konkret yang membentang dari 7 sampai 11 tahun yang melibatkan penggunaan konsep operasi, pemikiran logis, dan memiliki keterampilan mengklasifikasikan. Kegiatan kampanye dan penyuluhan membutuhkan kemampuan berpikir analitis, dimana peserta didik baru bisa berpikir logis. Hal ini perlu menjadi pertimbangan bagi penulis buku teks agar memperhatikan aspek karakteristik peserta didik.

\section{Authentic Assessment}

Muatan paper-pencil task yang tercantum pada buku teks, sebagian kecil masih menggunakan penilaian tradisional berupa pilihan ganda dan isian singkat. Hal tersebut tidak sesuai dengan tuntutan authentic assessment, sebagaimana yang disampaikan Nitko \& Brookhart (2011, p.248) bahwa "paper pencil task permit student not only to record their answer but also to give explanation, articulate their reasoning, and express their own approaches toward solving a problem". Paperpencil task mengizinkan peserta didik tidak hanya untuk merekam jawaban mereka, tetapi juga untuk memberikan penjelasan, mengartikulasikan alasan mereka, dan mengekspresikan pendekatan mereka sendiri terhadap pemecahan masalah. Kegiatan tersebut mengarah pada soal uraian. Hal yang disayangkan, kegiatan tersebut tercantum pada evaluasi setiap subtema yang menjadi evaluasi rutin untuk menilai peserta didik. Soal pada Buku Puskurbuk berupa soal uraian yang mengarahkan pada kemampuan mengekspresikan pendapat berdasarkan pemahamannya.

Buku teks Kurikulum 2013 menerapkan authentic assessment dengan kombinasi dari berbagai jenis penilaian untuk mengetahui kemampuan sesungguhnya yang diperoleh peserta didik. Kombinasi dari berbagai penilaian tersebut membantu guru untuk menggambarkan kemampuan peserta didik secara komprehensif dari aspek sikap, keterampilan dan pengetahuan Hal tersebut sejalan dengan Van Tassel-Baska (2013, p.43) bahwa “....different approaches can supplement one another to provide a more comprehensive picture of a student's performance". Pendekatan yang berbeda dapat melengkapi satu sama lain untuk memberikan gambaran yang lebih komprehensif pada kinerja peserta didik.. Hasil yang diperoleh tersebut juga dapat digunakan untuk kegiatan tindak lanjut guru dalam melaksanakan proses pembelajaran. Kombinasi penilaian tersebut mengarahkan pada rubrik yang digunakan untuk menilai peserta didik. Rubrik yang tersedia pada buku teks perlu dikembangkan guru lebih lanjut dan disesuaikan dengan setting kelas.

\section{PENUTUP}

Simpulan

Berdasarkan hasil penelitian dan pembahasan, maka dapat diperoleh kesimpulan sebagai berikut. (1) Semua buku teks yang dianalisis telah memenuhi sebagian besar muatan tematik integratif, yaitu pada aspek pengalaman bermakna dan student centered learning. Sebagian kecil indikator yang belum terpenuhi adalah pada aspek multidisipliner karena kekurang-telitian dan perbedaan pandangan yang digunakan oleh penulis. Kekurang-telitian tersebut berupa kesalahan 
penomoran KD yang sesuai dengan Permendikbud Nomor 67 Tahun 2013, dan ketidaksesuaian materi dengan KD yang tercantum. Kekurang-telitian banyak ditemukan pada buku Puskurbuk. Perbedaan pandangan berkaitan dengan hubungan antar mata pelajaran yang integrasikan dalam satu tema. Hubungan antar mata pelajaran yang ditemukan berupa materi yang berkaitan antar muatan mata pelajaran pada buku Non Puskurbuk 1 dan rangkaian cerita yang utuh pada pembelajaran yang dilengkapi dengan tokoh pada buku Puskurbuk dan Non Puskurbuk 2. (2) Semua buku teks yang dianalisis telah memenuhi semua muatan scientific approach. Kegiatan mengumpulkan informasi merupakan kegiatan yang mendominasi. Kegiatan tersebut pada buku teks terdiri dari berbagai kegiatan yang bervariasi meliputi mengeksplorasi, mencoba, melakukan percobaan, mengumpulkan data dan membaca sumber selain buku teks. Kegiatan yang bervariasi tersebut membantu peserta didik untuk menambah pengalaman belajar. Kegiatankegiatan tersebut menunjukkan bahwa peserta didik terlibat aktif untuk menemukan suatu konsep. Kegiatan-kegiatan scientific approach yang tercantum pada buku teks merupakan kegiatan dengan pendekatan konstruktivisme, yaitu mengarahkan peserta didik untuk berinteraksi dengan lingkungan fisik dan lingkungan sosial untuk membangun pengetahuan. (3) Semua buku teks yang dianalisis telah memenuhi sebagian besar muatan authentic assessment. Rubrik penilaian pada buku teks berupa contoh format penilaian yang dapat dikembangkan oleh guru. Muatan paper-pencil task yang tercantum pada buku teks, sebagian kecil masih menggunakan penilaian tradisional berupa pilihan ganda dan isian singkat. Muatan penilaian yang lain menggunakan kombinasi dari berbagai penilaian untuk membantu guru untuk menggambarkan kemampuan peserta didik yang sesungguhnya secara komprehensif dari aspek sikap, keterampilan dan pengetahuan.

Saran

Bagi BSNP diharapkan melakukan penilaian kelayakan terhadap buku teks yang tersebar di sekolah-sekolah, terutama yang diterbitkan oleh pihak swasta seperti Non
Puskurbuk 1 dan Non Puskurbuk 2 untuk memberi masukan kepada penulis dan penerbit agar menyesuaikan dengan Permendikbud yang berlaku. Bagi para guru diharapkan lebih selektif dalam memilih buku atau memilah materi dan kegiatan pembelajaran yang tercantum pada buku teks sebagai bahan implementasi kurikulum 2013 di kelas. Buku Puskurbuk sudah mencakup muatan tematik integratif, scientific approach, dan authentic assessment secara lengkap hanya saja kesalahan teknis akibat kekurang-telitian penulis yang perlu diperhatikan dalam implementasi di kelas. Guru juga perlu memperhatikan rubrik penilaian pada Buku Puskurbuk yang digunakan pada setiap kegiatan, agar menyesuaikan dengan setting di kelas. Buku Non Puskurbuk 1 dapat digunakan sebagai buku pendamping bagi guru, karena materi, kegiatan dan penilaian yang sudah lengkap, sedangkan Buku Non Puskurbuk 2 dapat digunakan sebagai buku pendamping bagi peserta didik karena berisi materi dan kegiatan yang bervariasi untuk mengekplorasi kemampuan peserta didik dirumah. Bagi penulis buku Puskurbuk diharapkan lebih teliti dalam melakukan pengetikan dan untuk menghindari kesalahan pengetikan terutama pada pencantuman nomor KD yang beberapa belum sesuai dengan Permendikbud Nomor 67 Tahun 2013. Selain itu, penulis buku Non Puskurbuk 2 dan Non Puskurbuk 1 juga perlu menghilangkan muatan soal pilihan ganda dan uraian singkat. Penulis buku Non Puskurbuk 2 juga perlu mencantumkan rubrik penilaian bagi setiap kegiatan yang dilakukan peserta didik. Bagi peneliti lain diharapkan melakukan penelitian yang relevan dari aspek yang berbeda diantaranya muatan pendidikan karakter, kompetensi sikap spiritual dan sikap sosial, dan pembelajaran yang menyenangkan (fun learning) Selain itu, peneliti lain juga dapat menganalisis buku yang berbeda untuk memberi informasi tambahan untuk kemajuan perbukuan nasional.

\section{DAFTAR PUSTAKA}

Adeyemi, D. A., (2010). Justification of a multidisciplinary approach to teaching language in Botswana junior secondary schools. The Journal of Language, 
Technology \& Entrepreneurship in Africa, 1, 8-20.

Al Hassan, I. B. M. (2012). Multidisciplinary curriculum to teaching english language in sudanese institutions (a case study). Theory and Practice in Language Studies, 2, 402-406.

Djuandi. (2014). Review buku teks kurikulum 2013 kelas xi kelompok peminatan. Diakses tanggal 15 Juli 2014 dari http://bsnp-indonesia.org.

Gerde, H. K., Schachter, R. E., \& Wasik, B. A. (2013). Using the Scientific Method to Guide Learning: An Integrated Approach to Early Childhood Curriculum. Early Childhood Education Journal, 41, 315323.

Ho, H \& Hsu, Y. (2011). Improving the textbook adoption process in Taiwan. International Education Studies, 4, 92-98.

Krippendorf, K. (2004). Content analysis: an introduction to its methodology, $\left(2^{\text {nd }} e d\right)$. California: Sage Publication Ltd.

Lalley, J. P, \& Miller, R. H. (2007). The learning pyramid: does it point teachers in the right directions?. Education, 1, 64-79.

Meinbach, A. M., Rothlein, L., \& Fredericcks, A. D. (1995). The Complete Guide to Thematic Units: Creating the Integrated Curriculum. Washington: ChristopherGordon Publishers, Inc.

Mendikbud. (2013a). Peraturan Menteri Pendidikan dan Kebudayaan Nomor 64, Tahun 2013, tentang Standar Isi Pendidikan Dasar Dan Menengah.

Mendikbud. (2013b). Peraturan Menteri Pendidikan dan Kebudayaan Nomor 71, Tahun 2013, tentang Buku Teks Pelajaran dan Buku Panduan Guru untuk Pendidikan Dasar dan Menengah.

Mendiknas. (2008). Peraturan Menteri Pendidikan Nasional Nomor 2, Tahun 2008, tentang Buku.

Niti Bayu Indrakrista. (2014). Distribusi buku kurikulum 2013 masih amburadul di DIY. diakses tanggal 7 September 2014 dari http://www.tribunnews.com/regional/2014 /08/12/distribusi-buku-kurikulum-2013masih-amburadul-di-diy.

Nitko, A. J., \& Brookhart, S. M. (2011). Educational assesment of student $5^{\text {th }}$. New Jersey: Pearson Education Inc.

Roseni, E. (2014). Albanian case: english textbook evaluation in high schools as part of the english curriculum. Mediterranean Journal of Social Sciences, 6, 417-421.

Rusman. (2014). Model-model pembelajaran mengembangkan profesionalisme guru. Jakarta: Rajawali Press.

Schunk, D. (2012). Learning theories: an educational perspective. (Terjemahan Eva Hamdiah \& Rahmat Fajar). New Jersey: Pearson Education, Inc. (Buku asli diterbitkan tahun 2010).

Santrock, J. W. (2009). Psikologi Pendidikan Jilid 1. (Terjemahan Diana Angelica). New York: Mc Graw-Hill. (Buku asli diterbitkan tahun 2008).

Settlage, J. \& Southerland, S.A. (2012). Teaching science to every child: using culture as a starting point $2^{\text {nd }} e d$. New York: Routledge.

VanTassel-Baska, J. (2013). Performance-based assessment the road to authentic learning for the gifted. Gift Child Today, 1, 41-47.

\section{Profil Singkat}

Degi Alrinda Agustina, lahir di Surabaya pada tanggal 19 Agustus 1991, pendidikan S1 diselesaikan tahun 2012 di FKIP Universitas Mataram pada Program Studi Pendidikan Kimia. Program magister diselesaikan di Program Pascasarjana Universitas Negeri Yogyakarta (PPs UNY) jurusan Pendidikan Dasar tahun 2015.

Ali Mustadi, lahir di Kudus, 10 Juli 1978, pendidikan S1 hingga S3 diselesaikan tahun 2011 di Universitas Negeri Semarang. Beliau juga mengikuti Doctoral Sandwich Program di Ohio State University, USA pada tahun 2009-2010. Saat ini, beliau sebagai dosen aktif di PPs UNY dan menjabat sebagai Sekretaris Program Studi S2 Pendidikan Dasar PPs UNY dengan bidang keahlian Pendidikan Bahasa Anak. 